\title{
The African Educational Evolution: From Traditional Training to Formal Education
}

\author{
Dama Mosweunyane ${ }^{1}$ \\ ${ }^{1}$ Department of Adult Education, University of Botswana, Botswana \\ Correspondence: Dama Mosweunyane, Department of Adult Education, University of Botswana, Botswana. \\ E-mail: mosweunyane@mopipi.ub.bw
}

Received: February 28, 2013 Accepted: April 2, 2013 Online Published: July 18, 2013

doi:10.5539/hes.v3n4p50 URL: http://dx.doi.org/10.5539/hes.v3n4p50

\begin{abstract}
This paper attempts to critically examine the approaches that were employed by Africans in their knowledge, skills and attitudes acquisition before, after and during colonialisation of the continent. The paper looks at three distinctive epochs from which the perfect understanding of how learning in Africa transformed could be concluded.

It is notable that there was a period before Africa got colonised, which was followed by the period during colonisation, before the independence of the continent. The position that is strongly advanced through this paper is that even before colonialism the African societies offered training to their members, which was characterized by the provision of survival skills to individuals who were supposed to selflessly serve their societies. Members of African societies learnt through their interaction with their physical and spiritual milieus, as evidenced by their design of tools which they used mostly in their agro activities and in fighting for resources. The other area in which learning took place was that of spirituality or mysticism, as some superstitious members of African communities were believed to have powers of communicating with their ancestors. As noted by Westerlund (1991), the belief in the ancestors is widespread in many African agricultural areas and like divinities and nature spirits, the spirits of ancestors are thought to be intermediaries between God and humankind. The main problem that this paper is intended to advance is that Africa is regarded by some people as having not had any form of education before the arrival of the colonialists and their educational establishments or organisations. This paper therefore raises an argument against this position.
\end{abstract}

Keywords: Africa, formal education, colonialism, traditional, independence, Westernisation

\section{Introduction}

This paper is meant to argue that most learning that occurred in Africa was necessitated to meet the exigencies of the whole society through training of its individual members either in groups or on individual basis. This approach fostered cooperation and collaboration amongst the community members and promoted the perfection of knowledge and skills before being transmitted to posterity. According to Vanqa (1995) essentially training was intended to enable an individual to play a useful role in society. The learning of the use of words and gestures to convey messages in the most eloquent way was emphasized and rewarded by both the traditional leadership and village elders. As noted by Emeagwali (2006) Africans at various parts of the continent used a wide range of symbols and motifs for communicating ideas. It is important to mention that the learning did not follow any comprehensive and formal curricula, which in most cases resulted in important knowledge and skills getting lost when the custodians of such knowledge and skills died or lost their cognitive abilities, such as going insane.

The traditional schools, such as Bogwera and bojale in Botswana, played an important role in packaging and passing indigenous knowledge and skills orally from generation to generation. The paper argues that they were impediments to the preservation of approaches that were employed in the training and learning by members of African societies because of the secrecy that surrounded how the processes were conducted. Most importantly, the paper will demonstrate that less emphasis in the documentation of what was supposed to be learnt compromised standardization and formalization of knowledge and skills.

The paper further argues that the infiltration of Western forces during colonialism facilitated the obtrusion of western knowledge systems into African societies, which undermined the essentiality of African indigenous 
knowledge systems and destroyed the zeal in Africans to modernize and ameliorate their systems. The infiltration of Western knowledge systems served to re-direct development of the African continent by emphasizing its making in the image of Europe and North America. The Eurocentric approaches, such as class lectures and teleconferencing make Africans undermine their own ways of transmission of knowledge. As noted by Boateng (1985) In Africa, the introduction of western formal education has often served as obstacles to the process of cultural transmission and intergenerational communication, which are viewed culturally as some of the functions of the school. One area which served as an important educational vehicle for the youth in traditional Africa was the oral literature. Oral literature encompasses fables, folktales, legends myths and proverbs.

The African continent experienced its own form of training and learning before it was colonized and even before the arrival of the missionaries. The training systems of Africans such as the traditional schools did exist, but most importantly, the family unit served as an important structure for knowledge provision and acquisition. It is important to mention that these training facilities got undermined as a result of importation and imposition of knowledge systems from colonial powers. In his lectures on the philosophy of history, Hegel as cited by Wilks (1971) is said to have stated that Africa is no historical part of the world; it has no movement or development to exhibit and that is why the colonial era should essentially be an age of enlightment.

Education was seen as a vehicle through which western cultures can be fostered or promoted in the African continent by its colonizers. This arrangement viewed Africans as having little or no knowledge of their own, which meant they had to learn advanced, organised, systematic or sophisticated skills. Therefore, education in Africa cannot be perfectly understood without first understanding the strengths and intentions of the very forces that gnarled it, which according to Mcgregor as cited by Adedeji (1990) was originally motivated by the desire to provide "moral" upright and honest Christian clerks, traders, interpreters and chiefs. It was also meant to produce Africans who could communicate fluently in the language of the colonial powers. An excellent example is that given by Iliffe (1979) who stated that, all instructions in a school in Tanzania was in French, Latin was studied in preparation for priesthood, and Swahili, which is an African language, was forbidden. Most importantly, as noted by Akinpelu (1981) the imposition of the Western education was meant to reinforce the colonial conditions by inculcating the values of the colonial society and training individuals for the service of the colonial state. It promoted the capitalist system, which feed on the individualistic instinct of mankind and induced in the attitude of human inequality and domination of the weak by the strong.

The African continent is underdeveloped, which leaves it with no choice but to accept what is imposed on it by the developed world as education. The world today is divided into 'advanced' or industrialised countries and 'underdeveloped' ones most of which are in Africa (Loomba, 1998). It is these divisions that will make Africa rely on what is determined by the developed countries as worthy of been learnt. This is possible chiefly because of the technology that serves to influence the African continent and the rest of the developing world.

This paper attempts to essentially advance an argument that education existed in what is today known as Africa but lacked the theoretical base. This was even before the continent got into contact with representatives of the civilized North. The limitations in the knowledge about what existed in Africa before colonial invasion can be attributed to lack of documentation to verify that knowledge and skills did exist in Africa long before what is known today.

The evidence that is available is often not accepted by the developed world or deliberately distorted, which disadvantages Africa and denies it an opportunity to be recognized in the global arena as ingenious or inventive. As noted by Boateng (1985), Western formal education did not consider cultural transmission as part of the educative process.

It is important to note that it would be difficult for Africa to retrieve its knowledge and skills that existed before the continent was besieged by Western powers. This is because of continued façade to keep the continent under western influence and control. As long as Europe dominates over Africa there is no how the latter's education systems can gain recognition. As noted by Asante (1987) any interpretation of Africa must begin at once to dispense with the notion that, in all things, Europe is teacher and Africa is pupil.

\section{African Traditional Education}

Education existed in Africa long before the continent was colonized or even before the slave trade. Knowledge, skills and attitudes were passed from generation to generation mostly through word of mouth in the African societies. This is because African societies, just like any other society, share the common ancestry which has led to the most unique characteristics, which is the ability to adapt the environment to suit the inhabitants. For instance, Leakey (1982) does indicate that the use of tools, the construction of huts, all suggest that human 
society, including African societies, became much complicated during the past million years. This complication, it has to be explained, was necessitated by the ever changing societal exigencies and the need to adapt to emerging changes. It is this understanding that provides enough evidence that African societies through interacting with their environments learnt skills that were required for them to survive.

The making of hunting tools for instance, characterized most African societies, mostly during the time they were peripatetic or nomadic. As noted by Vanqa (1995), wandering in the bush enabled members of African societies to know their immediate surroundings such as river systems, the hills and forests, the type of flora and fauna and other characteristics. This means knowledge and skills pertaining to resource management was unquestionably obligatory.

It has to be noted also that the knowledge that Africans had was scientific and as intricate as any other from other parts of the world. As noted by Emeagwali (2006) Africans while interacting with their environment and transforming various raw materials overtime, arrived at various hypotheses about nature, the natural world and society. The fabrication of metallic tools and implements, textile production, traditional medicine or food processing, involved the application of various techniques, principles, and propositions arrived at through observation of the environment and experimentation at various levels.

The knowledge and skills were shared with newly found members, such as those who were captured during battles or those who became members through birth and marriage. The learning about the environment also conveyed information about the measures that were employed by African societies in conservation of resources. For instance, in Southern Africa and other parts of the continent, taboos were used as a conservation strategy. For instance, an animal was not killed or eaten because it was respected as a totem.

The traditional schools were used to provide the necessary skills and knowledge that African societies needed for their survival. This qualifies as education if we are to borrow a definition by Moumouni as cited by Koma (1976) who said, education is everything that prepares the young people for either integration in a given specific society with the aim of perpetuating the established values and norms of such society or transforming and changing such values and norms.

The production of tools required skills for immediate use and their modification, which was determined by two distinct challenges. Firstly, the need for African societies to protect themselves against predators meant that tools had to be modified as new techniques and strategies of killing were devised. Secondly, the annexation of members of a tribe and other resources such as land necessitated tribal conflicts. The tribal conflicts meant that strategies in battle were important if the tribe was to maintain its identity and protect its resources. It was noted by Wilson (1975) that the African continent always had small communities which moved quite frequently, sometimes conflicting with each other. This situation often necessitated the mastery of the necessary strategies for society to survive, which promoted the learning of such strategies through demonstrations by the elderly to the young.

The African societies that got defeated were often conquered, subjugated and integrated into those that emerged victorious. This meant that new members were taught or learnt new values, cultures, strategies and skills. According to Pandey as cited by Abose and Kandjii-Murangi (1995) the children were required to have knowledge, skills and attitudes of societies in which they were born as in the traditional societies of the past all over the world; there was no clear separation between educational activities and socialisation. The knowledge, skills and attitudes as well as social norms, mores and values peculiar to a given group were learnt by the children, which meant that transfer of information which translates into learning took place.

The tribal battles also meant that devine intervention was always important as defeat was interpreted as a curse that is cast upon a society by its ancestors. This means that the African societies worshipped even before the arrival of members of Western societies who brought foreign religions such as Christianity to the continent. It is therefore palpable that African societies learned important facets to execute their functions of worship. It is disquieting that Iliffe (1979) notes that pre-literate, and the religions of pre-literate people not only leave little historical evidence but are characteristically eclectic, mutable, and unsystematic. With this it is important to acknowledge that some evidence can be extracted from what is surmised to have taken place within traditional schools; suggesting that the schools offered well-arranged training on religious practices.

\section{The Setting for African Traditional Education}

The elders were teachers in the African settings such as in the training of regiments for mastery of survival skills. According to Schepera (1938) the traditional schools systematically taught young adults a number of secret formulae and songs in Botswana, admonishing them to honour, obey, and support the chief; to be ready to endure 
hardships and even death for the sake of the tribe; to be united as a regiment and help one another; to value cattle as a principal source of livelihood, and herd them carefully; to attend public decision making meetings regularly, to honour and ungrudgingly obey old people and to keep religious practices (p. 106). For instance, according to Vanqa as cited by Abosi and Kandjii-Murangi (1995), Knowledge, customs and laws through tribal institutions were passed on to the young by the elders using proverbs and myths, which were told with care and repetition. The young were informed of their past and their cultural heritage with the aim of stimulating pride in cultural institutions which formed the basis of community's survival. It becomes clear gathering from what the preceding authors promulgated, that learning did take place within African societies even before the continent was besieged by colonialists and missionaries.

\section{The Curriculum}

It has to be noted that curricula did exist in the African societies though not in the manner that it is today. This explains why despite the existence of such curricula, writers such as Meredith (2006) stated that most African societies at the time they were colonised were predominantly illiterate and innumerate.

The training offered was not done haphazardly, but through some strategies that did not always conform to Western standards. This is despite existence of well-supported argument by writers such as Dugard (2003), to the effect that just like Egypt and the rest of Northern Africa, civilisations thrived in Southern and Central Africa for millennia. The Africans understood metallurgy, and made spears from iron and copper. Artisans wove fine cloths, baskets and beer was brewed from bananas and grain. Communication between villages and kingdoms was accomplished through a relay of swift runners (p. 5). It is indisputable that the exercise of processing information and passing it on through the word of mouth, which cannot be realised without learning, was achieved by 'primitive' African societies. The Western powers changed the way how Africans transmitted knowledge. As noted by Boateng (1985) the increasing deterioration of intergenerational communication in Africa has been attributed to systems of education introduced by Western colonial system (p. 109).

The scientific experiments though not conducted in laboratories as it is done today also took place. For instance, the fermentation of grains in the brewing of beer accorded African societies an opportunity to learn through observation and experimentation. These processes were repeated until they were mastered and were then packaged and passed on verbally for utilisation by future generations. It is imperative to state that knowledge was shared amongst communities and between generations, which was heavily influenced by the Africa notion that knowledge and information acquired was to enable its recipients to understand the reality of the world. This enabled society members to live in and become competent at solving their personal and social problems, as observed by Sunal (1998). It is therefore eccentric for anyone to suggest that no curricula existed before Africans came into contact with their colonisers. However, it has to be admitted that African curricula did not exist as documents that we see on modern age educational institutions such as the modern schools. As noted by Ocitti (1994) Pedagogically, African education encompassed both instructional and non-instructional models of learning, which may be termed formal, informal and unconscious.

\section{The Teacher in African Traditional Education}

Education in Africa served to uphold some African cultures, as it can be exemplified by what obtained in South Africa, where lifelong learning was imbued with the values, interests and behaviour patterns learned at the knee of a Bantu mother (Horrel, 1964). Interestingly, every member of an African society was a teacher by virtue of him and her having vast experience that was worthy. According to Moumouni (1968) when it is time for initiation, it will be under the direction of members of the community chosen for their knowledge, wisdom and experience, that the African adolescent learns the first elements of what is to be known physically and intellectually. Young men completed their training by listening to and observing the 'elders' at community 'palavers'.

African education combined both intellectual and manual labour which made the teachers to impart skills that were put to immediate use. The teacher in pre-colonial Africa never stopped learning, which means the teacher was also a learner. As noted by Koma (1976) knowledge was continually modified and innovations renewed, which strengthened the conviction amongst the African societies that life is a process of learning. As stated by Nyerere (1961) though pre-colonial Africa did not have schools in the modern sense, this did not mean that young people and children were not educated: they learnt by living and doing, which made their education essentially practical training. It is important to note that the teacher was viewed as a custodian of knowledge by the recipients of his/her training and what was taught was never questioned. This arrangement was meant to reinforce the concomitant absence of a tradition of questioning- combined with an essential top-down traditional culture of acquiescence before one's superiors. According to Datta (1984) the role of the teacher in Africa was to 
inculcate the dominant values, which the learners were to master and pass on to those younger than them. This means those who were trained had to play the role of teaching those younger than them and they had to display behaviour that the learners were to emulate. As noted by Bray, Clarke and Stephens (1986) indigenous education in Africa tend to reflect the values, wisdom and expectations of the community or wider society as a whole. This is contrary to Western forms of education, which tend to stress the intellectual development of the individual and pay less attention to the needs, goals and expectations of the wider society.

\section{Education in Africa during Colonialism}

Education did not start only after the famous Berlin conference of 1884-1885, which was Africa's undoing in more ways than one. As noted by Blij and Muller (2003) the colonial powers superimposed their domains in the African continent and by the time Africa regained its independence after the late 1950s, it could no longer fully regain its indigenous education. As noted by Margalit (2004) European ideas about politics were inevitably transmitted to the colonial subjects, along with science, religion, economics and literature (p. 38). The superimposition of colonial values on the African continent changed the lifestyle of Africans in many ways, which meant changes also in those things that Africans had to learn. The Africans received Western education which was meant to 'civilise them'. As stated by Mkandawire (2005) one task of education in both enslavement and colonialisation of Africa was to dehumanise the enslaved and the colonised by denying their history and denigrating their achievements and capacities. Adedeji (1990) points out that, the education introduced in what is Tanzania today was modelled on the British system, but with even heavier emphasis on subservient attitudes and on white collar skill. It emphasised and encouraged the individualistic instincts of mankind. It led to the possession of individual material wealth being the major criterion of social merit and worth. This meant that colonial education induced attitudes of human inequality, and in practice underpinned the domination of the weak by the strong.

Education in Africa during colonialism was used to convert Africans into foreign religions. For instance, in Botswana some schools were built by Catholics for purposes of providing Western education and religious teachings. According to Farouk (1998) the missionaries realised that African religion, art, music and other social activities were very closely connected with each other. The colonialists were not accommodative and aggressively wanted to replace any forms of learning that the African continent already had when they arrived. This was despite their understanding that changes can be effected on what society already has. For instance, between 1050 and 1200 BC changes took placed in England and Western Europe generally, which opened a new era in intellectual life and education.

It is important to note that the fundamental objective of Western powers was the steady enlargement of knowledge by the spread from Moslem Spain, ancient Greek and Arab learning, which the powers needed to enter into other parts of the world (Lawson and Silver, 1973, p. 18).

\section{Encounter with Western Education}

It is important to state that according to Buzan and Little (2000) Europeans occupied whole continents and stamped upon them a system of territorial boundaries, trading economics, and colonial administration. The few places that they did not reduce to colonial status (Japan, Siam, Persia, Turkey and China) were forced to adapt to European models to preserve themselves. It is clear that European conquests wanted to stamp their control without compromising. In Africa Africans were forced to change their ways of life by been converted so that they can adopt the Western culture. According to Awolalu (1991) converts in some parts of Africa were encouraged to flout authority by burning their ritual objects and breaking the taboos. The encouragement of the destruction of traditional objects of worship was enforced. In these operations, the educated Christians, who were mostly teachers and pastors, were used. They condemned the traditional title systems, marriage, rituals, songs, arts, and labelled them 'things of Satan'. The African dancing and music were banned from the curricula. Indigenous literatures in Africa's multitudinous tongues that had existed from time immemorial on the African continent were deemphasised. It is crucial to allude to the fact that when colonialism became a fact on the continent, the 'use of indigenous literatures, especially in formal schools, was relegated to the background or completely abolished. Before this destruction of African knowledge and its institutions, the colonial officials got knowledge about African languages, cultures and laws, which in many regions began to be compiled with the assistance of local intermediaries within the few years of occupation (Parker and Rathbone, 2007).

The colonialists or colonial agents had to learn African languages in order to operate effectively and churches were mostly used for that purpose. This means education was not only confined to the schools, but religious organisations were also used in the transmission of non-religious knowledge, which was meant to foster change amongst African societies. For example, the common root language, which Livingstone quickly learned was 
Bantu. As pointed out by Dugard (2003) the learning of languages of Africa involved amazing six hundred dialects which had spun from one tongue as tribes spread out across the continent in over a thousand of years. It is clear that learning amongst African societies was a continuous process, which was necessitated by societal interfaces. What should be emphasised is that the colonialists were autocrats; they made everything possible to destroy African traditions and institutions, wanting in their place to put those in the image of their own institutions (Osa, 1998, Kunene, 1992 and UNESCO, 1987). According to Adedeji (1990) Europeans wanted dominance in scientific, technical and managerial and educational fields, and opposed every effort by Africans to develop in those fields.

The other important area in which Africans were secretly trained was on witchcraft. According to Brain (1982), in African societies witchcraft did exist and was passed on from generation to generation by those who practiced it. It is important to indicate that witchcraft lacked scientific explanation in the Western sense, which made it less favourable. For instance, Brain (1982) indicates that, there was the widespread notion of a mystical power or force which can be tapped by elders through the medium of ancestral spirits and which traditionally was one of the most effective means of disciplining the young to obedience of the old (p. 373). It is lack of scientific evidence on witchcraft that provoked attempts to reject and abolish it by Western powers. According to (Iliffe, 1979) the common practice of the use of medicine to harm or protect, to ensure health and fertility in peace, safety and victory in war was common amongst African societies. Some medicines were herbal remedies, others purely magical. Some were common knowledge, others the property of guilds or individual specialists. The specialists were trained, which means that formed part of African education.

It is evident that learning that was brought into the African societies got structured to produce individuals who did not fully identify with the values of the continent. According to Koma (1976) The characteristics of colonial education are that it promoted and encouraged individualism, it regarded accumulation of wealth as a measure of success in life, and it conditioned those who received it to despise those who did not receive it, made its recipients despise manual work and made its victims accept anything European as the paragon of excellence. Boateng (1985) also states that, the traditional role of education- bridging the gap between the adult generation and youth- is gradually giving way to the development of the so-called creative individual who is completely removed from his/her tradition (p. 109).

It is important to indicate that Western education antagonised efforts by Africans to influence it and to appreciate the contributions made by Africans. As noted by Emeagwali (2006) for example, they are connections that exist between Egyptian mathematics and the so-called discoveries that made celebrities out of Greek scholars, such as Archimedes and Pythagoras. The written sources of African history such as works by Africans themselves namely: Hamadhari, Al Masudi, Al Bakri, Al Idrisi, Al Umari, Al Muhallabi were not taught in African institutions. Equally affected were significant African historical writtings of the twelfth and thirteen centuries such as, The Tarikh al of Sudan, The Tarikh al Fattash, The Kano Chronicle and The Chronicles of Abuja that are originally based on Orature (p. 231). The Africans that excelled in schools received scholarships to go and study in European and American universities, which further distanced them from their African cultures. The learning and teaching strategies and techniques that African societies had employed for lengthy durations were discarded. African education system was undermined at the expense of a more clearly defined form of structured learning which was introduced to the continent from the North.

The obtrusion of systematised training meant that choices were taken about its content, method and organisation, which reflected the relative power of the different classes and their ability to advance their own interests (Youngman, 1981). It is not surprising that in the 1950s the majority of parents and pupils saw that the way out of village economy was through the primary and the middle school system (Dodd, 1969).

Western education emphasised the use of foreign language such as English in the former British colonies like Botswana. It does not come as a surprise that Lawson and Silver (1973) indicated that, from the late fourteenth century, English gained social respectability with the gradual recognition of its suitability for business and literature, and its use in writing rapidly became general. What this arrangement meant was that African languages lost their importance in education and the language of the colonisers became useful in the imparting of knowledge and skills.

\section{African Indigenous Knowledge in a Globalised Education}

The modern African societies are submerged in Westernisation or are Eurocentric and Americocentric and they will never reconstruct their pre-historical identities. It is important to note that through globalisation the Western forces have achieved a milestone that cannot be easily re-arranged. According to Baylis and Smith (2006) globalisation as a secular historical process has occurred in three distinctive waves. The first wave was the age of 
discovery (1450-1850), when globalisation was shaped by European expansion and conquest. Second wave (1850-1945), evidenced a major expansion and spread and entrenchment of European empires and (1960 and on), which is a new epoch in human affairs characterised by microchip and satellite icons. As noted by Kortenaar (1995) one may not be able to return to the world of one's ancestors. It has to be noted that present rhetoric that is based on the misconception that Africa of the past can be revisited is practically impossible. It has to be admitted that the African continent is immensely benefitting from contemporary technological changes that take place in the world. It is important to indicate that due to contact with European civilisation, and the gradual spread of education, though in varying degrees, many of the thoughts and ways of life of Africans are completely different from what they used to be before and during colonialism as noted by Schapera (1938). It is self-evident that all knowledge is comprised of concepts and propositions, including concepts and propositions that deal with learning strategies and methods of conducting inquiries (Novak, 1998). It has to be noted that not only education but social reality has become schooled or institutionalised.

The schools guide lives and the worldview, and define what is legitimate and what is not, as averred by Illich (1971). Africa cannot take the risk of reverting to its pre-colonial educational systems because according to Bown \& Tomori (1979) with constant development in science and technology, with new means of communication such as radio and television, with major alterations in political institutions, any person 'who does not keep up-to-date with these changes is condemned to be overtaken. This reality does translate to mean that, it becomes difficult or almost impossible for Africa to revive its indigenous knowledge systems, some of which have been lost overtime. It is indisputable that Africa benefits immensely from the training that is offered by the West and North America. However, it is worth noting that this is realised or achieved at the expense of what Africans cherished as knowledge and skills before the arrival of Western colonisers. It has to be noted that according to Mkandawire (2005) African independence was associated with the right to industrialisation, which led to a remarkable expansion in all levels of education. It is important to note that education had been instrumental in the promotion of Western form of development.

Due to advanced technology, training can be done through institutions in Africa, Europe and United States of America and so on, which has universalised education. It has to be admitted that Western and North American training remains dominant in the modern era. However, it is also important to acknowledge the influence that the Chinese education system is having on education in Africa. The Chinese training, mostly in Mandarin, which is a language used in China, is gaining ground in Africa because it now constitutes part of curricula of some institutions in the continent. This translates to mean education in Africa is bound to be transformed so that it can be responsive to these emerging trends. According to Marginson (2011) education is meant to promote global connectedness, which sums all global systems in education and research (p. 14). This is despite the challenge of resistance that is been experienced in some parts of the continent. As pointed out by Fullick as cited by Leathwood and Francis (2006) there is already a healthy resistance to participation from many who regard the education on offer as middle-class and alien. Added to this blame is the one advanced by Owusu (1995) who stated that the increasing deterioration of intergenerational communication in Africa has been attributed to systems of education introduced by Western colonial system.

It is very difficult to indigenous education against the bedrock of a strongly held conviction in the era of globalisation. As pointed out by Scholte (2005) neo-liberalists have championed globalisation on a market led path in which public authorities only facilitate and in no way interfere with the dynamics of demand and supply. Reformists argue that globalisation should be deliberately steered with public policies, including substantially increased global governance and transformists advocate for globalisation that transcend currently prevailing social structures like capitalism or rationalism.

There is also a challenge faced by education in most African countries, which is of structuring education to be responsive to the demands and disciplines of the capitalist global economy. It is important to note that even the coalition of the 'Third World' cannot overcome the counterhegemonic forces some of which are responsible for the provision of education. It is important to conclude this section by admitting that education will continue to be defined by the powerful forces that control Global events and not so much by the African continent. This means Africa will continue to have less or no influence in the design of the curricula if it has to be recognised in the global village. It is chiefly important to note that, the emergence of globalisation has strengthened the justification for the use of Western concepts in the African education sector.

\section{Implications for Development in Africa}

According to Ake (1978), Africa does not have any choice but to maintain existing relations of production in the global economy. The extent of the financial, commercial and technological dependence of the African economies 
on the West does not allow them to isolate themselves. It has to be stated that the continent is also under siege by non-state actors such as multinational corporations. As noted by Seidman \& Makgetla (1980) the largest firms, the transnational corporations, took the lead in expanding their global operations into more profitable areas. They competed to discover new sources of raw materials, to pry for open markets for their growing surplus manufactured goods in the Third World. It is important to indicate that almost all African countries form what is referred to as the Third World. The presence of transnational corporations in the African countries has influenced the education systems in the continent. For example, in Botswana the mining giant company known as DeBeers is mining diamonds and has trained citizens in various areas, such as geology and mining engineering.

The continent's education cannot be alienated from the Western educational systems because as noted by Fiala (1994) education systems reflect and are shaped by ideological and organisational processes at the societal and world level. At the world level, ideological processes appear to have been associated with the extraordinary expansion of education systems following the Second World War.

It is important to note that even those scholars who are in favour of indigenous education are not dismissive of Western form of education. According to Gboku and Lekoko (2007) a formal education system can play an important role in Africa. Such a system if it is to meet the cultural, social, moral and intellectual, as well as political and economic needs of Africa it has to be adapted and integrated into indigenous form of education. It is proposed by Emeagwali (2006) that Africa should embrace both exogenous and endogenous technological activities for its advancement, which should be for realisation of both scientific and technological growth in areas of medicine, mathematics, metallurgy, ceramics, textile, food processing and building technology.

It is important to note that even proposals on how Africa should develop advocate for the utilisation of already existing approaches and institutions. For instance, according to Mengisteab (1996) the transforming of peasantry, development of domestic markets, mobilisation of the general population through broad popular coalitions, as well as establishment of democratic systems should be presented as prerequisites for the development of Africa. It has to be appreciated that globalisation is old and it will be difficult if not impossible to dismantle it.

\section{Conclusion}

It is very important to conclude by indicating that Africa had its own form of education that made African societies to survive. The arrival of the colonial forces embarked on an agenda to make African knowledge and skills to be inconsequential and engaged in an undertaking to replace them. Even where African institutions were researched on and found to be credible, such as Egyptian civilisation, they were not accommodated in the education of the Africans in the manner that would have made them to have a sense that they were equally capable and had a history worth studying. To a large extent it has to be admitted that the colonial powers did achieve their objective of an intrusion of a foreign education in the continent. It has to be noted that indigenous knowledge, skills and attitudes were important for the continent of Africa because they were relevant and the continent would have advanced if it was left to develop its education systems. It can be concluded that it is necessary for more research to be done to unearth important knowledge systems that belong to Africa, which can be utilised in the economic, political and social advancement of the continent.

It is important to admit that it will be impossible to retrieve the knowledge, skills and attitudes that existed in Africa before the continent experienced colonialism because in majority of cases no documentation that is reliable can be found. The infiltration of foreign educational systems that took place and continue to take place have benefitted and continue to benefit the Africans so much that they will resist any effort geared towards taking them to the form of education that Africa had before colonialism. It has to be noted that the African continent is part of the 'global village' and cannot in its current economic, social and political situation afford to function in isolation. This means the technological advancement that is so far realised will remain attractive to Africans, which will further compound the problem of indigenisation. It has to be admitted that the African continent has experienced changes that are important for its education system to alien, if it has to remain on course in adding value to the development of the continent. It will also benefit the continent to encourage African scholars who are in the continent to conduct research in order to salvage what can be of use in giving the world a new understanding about the continent's knowledge systems.

\section{References}

Abosi, O. C., \& Kandjii-Murangi, I. (Eds.). (1995). Education in Botswana: A reading text. Gaborone: Macmillan.

Adedeji, A. (1990). Introduction. In ACARTSOD (Ed.), The African social situation: Crucial factors and development and transformation. London: African Centre for Applied Research and Training in Social 
Development (ACARTSOD).

Ake, C. (1978). Revolutionary pressures in Africa. London: Zed Press.

Akinpelu, J. A. (1981). An introduction to philosophy of education. London: Macmillan.

Asante, M. K. (1987). The Afrocentric ideas. Philadelphia: Temple University Press.

Awolalu, J. O. (1991). The encounter between African traditional religion and other religions in Nigeria. In J. K. Olupona (Eds.), African Traditional Religions in contemporary society. Minnesota: Paragon House.

Baylis, J., \& Smith, S. (2006). The globalisation of world politics: An introduction to international relations. New York: Oxford University Press.

Blij, H. J., \& Muller, P. O. (2003). Geography: Realms, Regions and Concepts. Retrieved May 27, 2011, from http://wysinger. Homestead. Com/berlinconference.htlm

Boateng, F. (1985). African traditional education: A tool for intergenerational communication. In M. K. Asante, \& K.W. Asante (Eds.), African Culture. London: Greenwood Press.

Bown, L., \& OluTomori, S. H. (1979). A handbook of Adult Education for West Africa. London: Hutchinson University Library for Africa.

Brain, J. L. (1982). Witchcraft and development. African Affairs, 81(324), 371-384.

Bray, M., Clarke, P. B., \& Stephens, D. (1986). Education and society in Africa. London: Edward Arnold.

Buruma, I., \& Margalit, A. (2004). Occidentalism. New York: The Penguin Press.

Buzan, B., \& Little, R. (2000). International systems in World History. Oxford: Oxford University Press.

Datta, A. (1984). Education and society: A sociology of African Education. London: Macmillan.

Diop, C. A. (1991). Civilisation or barbarism. Paris: Lawrence Hill Books.

Dodd, W. (1969). Education for self-reliance in Tanzania. New York: Teachers College Press.

Dugard, M. (2003). Into Africa. London: Transworld Publishers.

Emeagwali, G. T. (2006). Africa and the textbooks. In G. T. Emeagwali (Ed.), Africa and the academy (pp. 1-30). Trenton: Africa World Press, Inc.

Farouk, M. K. (1998). Citizenship education in Sub-Saharan Africa. In L. Susal (Ed.), Schooling in Sub-Saharan Africa: Contemporary issues and future concerns. New York: Garland Publishing, INC.

Fiala, R. (1994). Educational ideology and the school curriculum. In A. Benavoy, C. Braslavsky, \& N.Truong (Eds.), School Knowledge in comparative and Historical Perspective (pp. 15-334). Hong Kong: Springer.

Gboku, M., \& Lekoko, R. N. (2007). Developing programmes for adult learners in Africa. Gaborone: Pearson.

Iliffe, J. (1979). Modern history of Tanganyika. London: Cambridge University Press. http://dx.doi.org/10.1017/CBO9780511584114

Illich, I. (1971). Deschooling society. New York: Harper Publishers.

Koma, K. (1976). Education in black Africa. Mahalapye: Botswana National Front Secretariat.

Kortenaar, N. (1995). Beyond authenticity and creolization: Reading Achebe writting culture. PMLA, 110(1), 30-42. http://dx.doi.org/10.2307/463193

Kunene, D. P. (1992). African, language literature: Tragedy and hope. Research in African literature, 23, 7-15.

Lawson, L., \& Silver, H. (1973). A social history of education in England. Bristol: J. W. Arrowsmith Ltd.

Leakey, R. (1982). Human Origins. London: Hamish Hamilton.

Leathwood, C., \& Francis, B. (Ed.). (2006). Gender and lifelong learning. London: Routledge.

Loomba, A. (1998). Colonialism/Postcolonialism. London: Routledge.

Marginson, S. (2011). Imagining the global. In R. King, S. Marginson, \& R. Naidoo (Eds.), Handbook on globalisation and higher education (pp. 10-39). Northampton: Edward Elgar Publishing Limited.

Mengisteab, K. (1996). Globalisation and autocentricity in African's development in the $21^{\text {st }}$ century.

Meredith, M. (2006). The state of Africa. London: The Free Press.

Mkandawire, T. (2005). African intellectuals and nationalism. In T. Makandawira (Ed.), African intellectuals (pp. 
10-55). New York: Zed Books.

Moumouni, A. (1968). Education in Africa. London: Andre Deutsch.

Novak, D. (1992). Education and politics in the 1990s: Conflict or consensus. Hong Kong: Burgess Science Press.

Nyerere, J. (1961). Ujamaa. Dar es Salaam: Oxford University Press.

Ocitti, J. (1994). African indigenous education: As practiced by the Acholi of Uganda. Nairobi: East African Literature Bureau.

Osa, O. (1998). Using indigenous literatures in Sub-Saharan African schools. In L. Susal (Ed.), Schooling in Sub-Saharan Africa: Contemporary issues and future concerns. New York: Garland Publishing, INC.

Owusu, M. (1995). Culture, Colonialism, and African Democracy: Problems and Prospects. In W. C. Michael, jr., \& L. Plotnicov (Eds.), Africa in World History: Old, New, Then and Now (pp. 141-160). Pittsburgh: University of Pittsburgh.

Parker, J., \& Rathbone, R. (2007). African History. New York: Oxford University Press.

Schepera, I. (1938). A handbook of Tswana law and customs. Hamburg: Munster.

Scholte, J. A. (2005). Globalisation: A critical introduction. New York: Palgrave.

Sunal, S. (1998). Schooling in sub-Saharan Africa: Contemporary issues and future concerns (ed) 'Overview of schooling in Sub-Saharan Africa. London: Garland Publishing, Inc.

UNESCO. (1987). Priority needs and regional cooperation concerning youth in English-speaking Africa.

Vanqa, T. P. (1995). History of Education. In C. O. Abosi, \& I. Kandjii-Murangi (Eds.), Education in Botswana (pp. 1-41). Gaborone: Macmillan Botswana Publishing (Pty) Ltd.

Westerlund, D. (1991). 'Insiders' and 'Outsiders' in the study of African religions: Notes on some problems of theory and methods. In J. K. Olupona (Ed.), African traditional religions in contemporary society. St.Paul, Minnesota: Paragon House.

Wilks, I. (1971). African historiographical traditions, old and new. In J. D. Fage (Ed.), Africa discovers her past (pp. 7-52). London: Oxford University Press.

Wilson, D. (1975). A history of South and Central Africa. Cambridge: Cambridge University Press.

Wilson, D. (1975). A history of South and central Africa. London: Cambridge University Press.

Youngman, F. (1981). Adult education in Botswana 1960-1980: An annotated bibliography. Gaborone: National Institute of Development and Cultural Research (NIR) Documentation Unit.

\section{Copyrights}

Copyright for this article is retained by the author(s), with first publication rights granted to the journal.

This is an open-access article distributed under the terms and conditions of the Creative Commons Attribution license (http://creativecommons.org/licenses/by/3.0/). 